\title{
Among the Headless Hordes: Missionaries, Outlaws, and Logics of Landscape in the Wittebergen Native Reserve, c. 1850-1871*
}

\author{
Rachel King ${ }^{1,2}$ \\ ${ }^{1}$ Centre of African Studies, University of Cambridge \\ ${ }^{2}$ Rock Art Research Institute, University of the Witwatersrand \\ Centre of African Studies \\ Alison Richard Building \\ 7 West Road \\ Cambridge CB3 9DT \\ United Kingdom \\ rk547@cam.ac.uk
}

Abstract In 1850 the Cape Colony and the Wesleyan Missionary Society jointly established the Wittebergen Native Reserve with two aims: 1) through Christianity and peasant labour, to control the nomadism of the 'acephalous' peoples dispersed by early nineteenth-century frontier conflicts; and 2) to curb the power of Moshoeshoe I's Sotho nation by acting as a buffer between his people and potential ally nations to the south and west. While these missions broadly resonate with 'colonisation of consciousness' projects, the significance of Wittebergen lies in its asyet-unexplored position as a node in a landscape crafted by peripatetic raiding polities. This paper treats land as idiom and object to explore how missionaries, administrators, settlers, and Africans negotiated identities in the nineteenth-century. I discuss how European land idioms emphasising tenure, security, and sedentism engaged with those of African polities that emphasised relationships between chiefly authority, deliberate lawlessness, and aspects of the landscape. Employing new

\footnotetext{
* A version of this paper was presented at the 'Missionaries, Materials, and the Making of the Modern World' conference at Cambridge, 15-17 September 2014. I thank the conference organisers, Chris Wingfield and Karen Jacobs, and the following colleagues for their comments on that presentation and drafts of this paper: Ceri Ashley, Zoë Crossland, Paul Lane, Mark McGranaghan, Luíseach Nic Eoin, Natalie Swanepoel, and Nick Zachariou. I am especially grateful to Robert Ross and William Beinart for valuable comments on an earlier draft of this paper. Photographs are reproduced with kind permission of the Council for World Mission archives at the School of Oriental and African Studies. Portions of this research were funded by a Clarendon Scholarship from the University of Oxford, and further research and writing were conducted during my tenure as Smuts Research Fellow in African Studies at Cambridge. I thank the Smuts Memorial Fund for their generous support.
} 
material and archival perspectives, this paper explores how Wittebergen's fields, mountains, and homesteads became the terms of a debate linking land tenure with social identities and lawlessness.

Keywords: Wittebergen Native Reserve, Basutoland, Wesleyan Missionary Society, land tenure, Basotho, BaPhuthi 


\section{Introduction}

I saw you at the top of your rock scarps, in a natural fortress [...] I gave you a beautiful country [...] You, Morosi, when I raised you you were a Moroa, you'd hardly a skin to cover your body. - Moshoeshoe I, $1847^{1}$

A few years ago this country was a dark corner unsafe for the habitation of civilized man, only the resort of Bushmen and banditti who made inroads into the Colony, now converted into a fruitful field. - J.P. Bertram, $1849^{2}$

These statements speak volumes about, among other issues, land; not only as property, raw capital, or as physical and environmental features but as something experienced subjectively. Moshoeshoe's statement - which carried some rhetorical weight - referred to land as the difference between a chief and a Moroa (Sesotho, 'Bushman'). Moorosi and his polity led a fairly peripatetic way of life while maintaining settlements and herds of cattle, ${ }^{3}$ but without rights to land emanating from a paramount chief they remained Baroa. In his letter to his Wesleyan brethren in London, Bertram described how the Wittebergen mission station calmed an area troubled by cattle raiding by sowing the seeds of growth - figuratively and literally, as Wittebergen's agricultural success contributed directly to its spiritual success. In both men's words, land is a way of talking about authority, aspiration, and disorder. Talk of land is also talk of mobility: how people moved through a landscape, and how these movements related to settlement and unrest. Land is both idiom and object: its use, allocation, physicality, and perception all influenced the ways in which people thought about, for instance, security, labour, and Christianisation. These three themes run through this essay. At its core is the proposal that an archaeological perspective on land and mobility can provide insight into the logics of how people moved through and assembled the world around them. As I explain shortly, this does approach does not necessarily privilege excavated remains but rather offers a way of engaging with archival and material sources. The Wittebergen Native Reserve (Figure 1) in the mid- to late-nineteenth century (ultimately incorporated into the Herschel District) offers a useful theatre in which to explore these ideas. The Reserve's administration (by officials) and ministration (by missionaries) aimed to spatially group residents based on idealised ethnic affiliation and encourage them to become settled, commercially-oriented farmers. In so doing, the Reserve would function as both a source of native labour and a check on the ability of chiefs to recruit followers and power. Mobility and itinerancy were

${ }^{1}$ C. Schrumpf, 'Assemblée national à Béthesda', Journal des Missions Évangéliques, 1847, p. 294-295, translation mine.

2 SOAS Wesleyan Methodist Missionary Society (hereafter WMMS), FBN 20, Box 315, J.P. Bertram to Secretaries General of the WMS, 9 November 1849.

${ }^{3}$ R. King and S. Challis, 'The Interior World of the Nineteenth-Century Maloti-Drakensberg Mountains', Journal of African History (in press). 
incompatible with these aims: people who refused to settle, become agriculturally productive, and cease raiding cattle within and around the Reserve were designated as squatters and undesirables. However, Wittebergen was established within a landscape that for many was characterised by precisely this sort of undesirable mobility. As with many places in southern Africa, the area around the Reserve was a major thoroughfare for cattle raiders and people seeking to distance themselves from the violent conflicts on the edges of the eastern Cape, the Orange Free State, and Moshoeshoe's BaSotho chiefdom. The mis-alignment of these 'logics of landscape' created opportunities for those within and around the Reserve to engage with ideas about mobility and settlement through their use of the physical and built environment, and transgressing the Reserve's borders.

That space and land (its arrogation, administration, and conceptualisation) are linked to the making of social categories and governance has a notorious pedigree in southern Africa, from early explorers to the Bantustans of the apartheid regime. Nineteenth-century native reserves became part of a tradition of state-sanctioned spaces in which land and mobility were contested, and where behaviours and subsistence within those spaces were (theoretically) regulated. ${ }^{4}$ In this sense, Wittebergen was part of a process that Lindsay Braun has dubbed 'cadastralisation', which drew in missionaries and government alike. ${ }^{5}$ As the colony and cadaster expanded east from Cape Town, the latter offered a powerful means of rendering the peoples of the frontier and beyond intelligible, and by extension manageable. Spatially demarcating people according to ethnic affiliation made the complexities of African polities legible to colonial authorities. Thus tribalised and territorialised, these peoples could be induced to shift their conceptions of land from (much reified) traditional, communal resource to alienable commodity.

Inasmuch as space could be planned by those with the power to do so, others could of course have different perceptions of land and space that were subject to distortion or mis-perception by those doing the planning. ${ }^{6}$ Historical geographers remind us that taking space as a subject of enquiry enables an understanding of 'how [people] generate a sense of [...] identity and how they narrate and situate their own histories', especially in a colonial milieu. ${ }^{7}$ Colony and mission established themselves in a world with multiple logics of land use and rights, flexible borders, changeable toponyms, and different meanings attached to mobility and sedentism. Missionaries and officials attempting to make sense of these settings had to contend

\footnotetext{
${ }^{4}$ A. Lester, 'Settlers, the State, and Colonial Power: The Colonization of Queen Adelaide Province, 1834-1837', Journal of African History, 39, 2 (July 1998); R. Ross, The Borders of Race in Colonial South Africa: The Kat River Settlement, 1829-1856 (Cambridge, Cambridge University Press, 2014).

${ }^{5}$ L.F. Braun, Colonial Survey and Native Landscapes in Rural South Africa, 1850-1913 (Leiden, Brill, 2015.

${ }^{6}$ E.g. H. Lefebvre, The Production of Space, trans. D. Nicholson-Smith (Malden, MA, Blackwell, 1991), p. 62-63.

${ }^{7}$ A.P. Hudson, Creek Paths and Federal Roads: Indians, Settlers, and Slaves and the Making of the American South (Chapel Hill, University of North Carolina Press, 2010), p. 2.
} 
with these many local creations of land through both memory and use. ${ }^{8}$ These actors had beliefs regarding space, mobility, and identity that were enacted within Wittebergen, and that are accessible through archival and archaeological approaches.

This brings me to what makes my discussion archaeological - its focus on land as both constructing and constructed. I do not mean this in an environmentally deterministic sense, but rather to describe how landscapes (past and present) are composed of dynamic relationships between humans and non-humans, organics and inorganics, and that these relationships constituted perceptions of land and environment. An archaeological view considers how moving through a landscape was a way of thinking about that landscape, its elements, affordances, and affective abilities. This position does not necessarily presume that people interacted with or traversed landscapes according to a pre-existing mental template; it allows for these interactions and movements to constitute a process of creation, of information gathering, of figuring things out. ${ }^{9}$ These experiences varied among individuals and communities; the resulting mis-perceptions or mis-alignments offer opportunities to observe different sorts of intelligence about the world and one's place in it. This mode of enquiry, then, is positioned to take land as its subject across a range of source materials - objects, topography, architecture, texts, and photography - while being attentive to the differences and disparities between these. ${ }^{10}$ In focusing on Wittebergen, my discussion is situated amidst earlier treatments by William Beinart, Colin Bundy, and Helen Bradford. ${ }^{11}$ Here, I want to tie together these conversations and give Wittebergen's missionaries a more full treatment than they have enjoyed hitherto. I take Wittebergen as an opportunity to explore how land and space emerged as key idioms referencing settlement, mobility, Christianity, labour, and security amidst imperfect knowledge of African politics.

\footnotetext{
${ }^{8}$ R.B. Craib, Cartographic Mexico: A History of State Fixations and Fugitive Landscapes (Durham, Duke University Press, 2004), p. 11-12.

${ }^{9} \mathrm{~N}$. Thrift, 'Intensities of Feeling: Towards a Spatial Politics of Affect', Geografiska Annaler, 86 B (2004).
}

${ }^{10}$ Space does not permit elaboration on theoretical frameworks. Archaeologists will note that I draw on discussions tying together landscape phenomenology and affective fields. E.g. B. Voss, The Archaeology of Ethnogenesis: Race and Sexuality in Colonial San Francisco (Berkeley, University of California Press, 2008), p. 147-151; O. Harris, 'Emotional and Mnemonic Geographies at Hambledon Hill: Texturing Neolithic Places with Bodies and Bones', Cambridge Archaeological Journal, 20, 3 (October 2010).

${ }^{11}$ W. Beinart, 'Amafelandawonye (the Die-Hards): Popular Protest and Women's Movements in Herschel District in the 1920s', in W. Beinart and C. Bundy (eds), Hidden Struggles in Rural South Africa (London, James Currey, 1987); C. Bundy, The Rise and Fall of the South African Peasantry (Cape Town, James Currey, 1988); H. Bradford, 'Peasants, Historians, and Gender: A South African Case Study Revisited, 1850-1886', History and Theory, 39, 4 (December 2000). 


\section{2. 'Let there always be a "native reserve""}

I want to begin by drawing out some idioms of land that emerge in other settlement projects in the WMS's tenure in southern Africa. To be clear, I am not attempting to draw a causal connection between these episodes or imply that they are 'test runs' for Wittebergen; especially as these earlier projects employed different principles governing land use and ownership. Rather, I want to highlight points where we can observe missionaries' ideas about land and geo-politics manifest in the practices of managing, reforming, and critiquing settlement projects. As these logics of landscape were made visible, it becomes possible to observe how tropes or pre-conceptions about African land use and mobility shaped ideas about order, disorder, and sedentism.

Broadly, Wittebergen's roots lie in the WMS's statist idiom of reserves designed to achieve security and harness the labour potential of African polities dispersed during the nineteenth century. An operating principle of WMS missions was to support minor leaders and fragmented communities over powerful chiefs, as the former were less likely to resist colonial expansion. ${ }^{12}$

Shortly after William Shaw arrived in the eastern Cape in 1820, he embarked upon an ambitious project: to establish a chain of WMS stations stretching east from the Keiskamma River beyond the boundaries of the Cape Colony, ministering to polities seen as weaker than the region's dominant Xhosa and Zulu powers (Figure 1). ${ }^{13}$ Fiona Vernal has described this chain as embodying a model of the mission station 'as a sacred island in a sea of heathenism' and 'as a beacon' for Africans. ${ }^{14}$ As with other stations built to this ideal, Shaw's chain attracted landless and dispersed peoples, many of whom were interested in residing at or around the mission station in order to gain access to land and missionary protection without necessarily converting. While missionaries had designs on instilling Christian behaviours, attitudes, and attachments to material culture, within this model it was difficult to convince many Africans to renounce their traditions. Consequently, missionaries allowed many people to live at the stations without converting or while making cursory gestures of Christianisation, in the hope that true conversion would follow. Shaw's chain of stations also sought to forge relationships with 'friendly' chiefs such as Faku of the Mpondo and Khama of the Gqunukhwebe - who could be made into British allies in the on-going frontier conflicts. ${ }^{15}$ This assistance was partly contingent upon chiefs ordering their followers to cease all activities perceived as

\footnotetext{
12 T. Keegan, Colonial South Africa and the Origins of the Racial Order (London, Leicester University Press, 1996), p. 134.

${ }^{13}$ W.D. Hammond-Tooke (ed), The Journal of William Shaw (Cape Town, A.A. Balkema, 1972), p. 9.

${ }^{14}$ F. Vernal, "'A Truly Christian Village": The Farmerfield Mission as a Novel Turn in Methodist Evangelical Strategies, Eastern Cape, South Africa, 1838-1883', South African Historical Journal, 61, 2 (May 2009), p. 412.

${ }^{15}$ T.J. Stapleton, 'Faku, the Mpondo and Colonial Advance in the Eastern Cape, 1834-53', in C. Youé and T. Stapleton (eds), Agency and Action in Colonial Africa: Essays for John E. Flint (Basingstoke, Palgrave, 2001).
} 
criminal, especially stock theft. Shaw later recalled explaining that 'unless they would put an end to these marauding expeditions [...], it would be of little benefit for me to dwell among them; and that peace which they professed to desire with the English could not be maintained. ${ }^{\prime 16}$ Shaw credited his influence with what he perceived as the complete cessation of cattle raids by certain polities, including the Gqunukhwebe.

Following Vernal, the Farmerfield mission signaled a 'novel turn' in the missionary enterprise at the Cape and illustrates how Shaw's efforts to establish a 'select class' of Africans aimed to correct the 'nominal' conversions of the earlier 'pioneer missions' ${ }^{17}$ Located within the Cape's boundaries, Shaw established Farmerfield between 1838-1839 at the request of African Methodists in Grahamstown, who wanted access to arable land upon which to pursue economic independence while living Christian lives. Unlike at the pioneer missions, where Africans could reside without converting, Farmerfield's residents had to adopt a 'public persona' committing to Christianity and renouncing African traditions. Public Christian personas included the rectilinear housing styles, modes of dress, and other changes that have become familiar features of mission endeavours in southern Africa. Although people could certainly dissemble, their actions, church attendance, worship, other Christian gestures were strictly enforced and were subject to community scrutiny. These gestures included ones related to livelihood and land, with settled agriculture and transhumant pastoralism, whether autonomously or in service to whites, becoming Farmerfield's economic pillars.

In contrasting the pioneer stations with Farmerfield, Vernal draws attention to a new model of missionisation and specifically to Shaw's changing ideas about settlement projects. Farmerfield was a space for 'mature Christians' - tenants willing to publicly commit to a Christian lifestyle and who had the means (especially livestock and the ability to pay an annual fee) to support themselves through agriculture and service. Writing in his 1860 memoir, Shaw described how he saw land access within the 'civilising mission' in southern Africa:

There should be ample reserves of lands of average value made for [Africans] in all parts of a territory [...] For a time these lands should be legally vested in trustees[...T]here should be a proviso, that as soon as any of the natives erect appropriate dwellings, and are presumably acquainted with the rights and privileges arising from the ownership of real property, they should receive legal titles, vesting their own lands in their own names in the usual manner[...] The result in the course of time would be, that the idle and worthless would dispose of their landed property, and could be compelled [...] to secure for themselves means of

\footnotetext{
${ }^{16}$ W. Shaw, Story of My Mission in South-Eastern Africa (London, Hamilton, Adams and Co., 1860), p. 365.

${ }^{17}$ F. Vernal, The Farmerfield Mission: A Christian Community in South Africa, 1838-2008 (Oxford, Oxford University Press, 2012), p. 139-141.
} 
subsistence; while the more industrious and sober would be found, as a class, to rise in character, and support themselves in comfort on their own homesteads and allotments. ${ }^{18}$

However, as Farmerfield would demonstrate shortly after these memoirs' publication, land access did not guarantee Africans' social and spiritual betterment in the face of larger structural inequalities and environmental conditions. War and drought undermined Farmerfield's productivity and encouraged tenants to seek work elsewhere, contributing to a growing sense that the mission's agricultural success was doomed by Christian nominalism. ${ }^{19}$ Farmerfield illustrates how the success or failure (real or perceived) of an agricultural mission was tied to productivity, the degree to which itinerant labour could be limited, and the public scrutiny of Christian disposition.

WMS experiences of Queen Adelaide Province - Governor Sir Benjamin D'Urban's and Lieutenant Governor Harry Smith's short-lived experiment in instilling British culture in select Africans - further illustrate how efforts to culturally convert Africans in situ implicated intertwined ideas about mobility, agricultural productivity, and the need to spatially and ethnically demarcate residents. For both the WMS and British settlers, the Province was an opportunity to mould a vision of native society amenable to creating labour on the eastern Cape frontier. ${ }^{20}$ Acquiring the Province made manifest settler ideology that yoked land acquisition and productivity to the belief in rightful and righteous expansion of whites to the interior. ${ }^{21}$ In the WMS idiom, land tenure at Queen Adelaide Province was a reward for good Africans and its punishment a revocation for bad ones. Shaw argued that land grants be made to chiefs proven 'friendly' during the War of Hintsa, preferably near farms to allow opportunities for labour and a rough sort of integration with white communities, thus establishing an enclave of loyalist Africans while evicting Rharhabe Xhosa. ${ }^{22}$ Thus, the Gqunukhwebe chief Khama received a place in the Province based in part on his apparent conversion and the assistance he had provided to the British. ${ }^{23}$ The relationship that the missionary William Shepstone cultivated with Khama in the Province laid the foundation for what would become Wittebergen.

Queen Adelaide Province permits a window onto idioms of land in dialogue. Xhosa knowledge of the landscape's impenetrable aspects allowed them to resist expulsion from the Province, requiring that the new regime 'civilise' them in situ through churches, police stations, magistracies, and technological and gender

\footnotetext{
${ }^{18}$ Shaw, My Mission, p. 144.

${ }^{19}$ Vernal, “"A Truly Christian”', p. 425-426.

${ }^{20}$ Keegan, Colonial, p. 140-5.

${ }^{21}$ A. Lester, Imperial Networks: Creating Identities in Nineteenth-Century South Africa and Britain (London, Routledge, 2001), p. 85-88; Ross, Borders, 134-136.

${ }^{22}$ Shaw, My Mission, p. 3-4; Lester, 'Settlers', p. 229, 240.

${ }^{23}$ Shaw, My Mission, p. 3-4.
} 
transformations in agriculture. ${ }^{24}$ Settlers saw land allocation as implicated in personal safety, debates over owner-occupation versus commercialisation of land, and endorsement of their role in the Colony's protection. Thus, many settlers favoured a defensive view over an assimilationist one, calling for land grants as buffers against the Xhosa. ${ }^{25}$ Concerning these ideas about security, it is worth bearing in mind Lester's observation that while settler emigration to the interior was certainly spurred on by commercial concerns, we should also emigration motivated by the loss of settler autonomy and ability to deal with perceived native threats that followed from humanitarian legislation. ${ }^{26}$

Queen Adelaide Province ceased to exist in 1836 when humanitarian interests won out over settler expansionism and Lord Glenelg, the Colonial Secretary in London, returned the land to the Xhosa. ${ }^{27}$ Over the next decade, settlers continued to expand into the interior, including into the area between the Kraai and Klaas Smits Rivers, many in the hopes of one day being re-annexed to the Cape. ${ }^{28}$

From the perspective of the WMS, agricultural missions and reserves represented sources of stability and even buffers against African chiefs. Indeed, Shaw extolled the virtues of reserves in his memoirs, writing, 'let there always be a native reserve.' However, these projects worked as long as African residents within these settlements could be persuaded to stay there. Itinerancy undermined the success of agriculturist enterprises and jeopardised security, in addition to making public engagements with Christianity challenging to observe. Both mission-as-beacon and mission-as-reserve models sought to 'domesticate' African movement but confronted several troublesome assumptions about land and mobility: that the land itself would cooperate (in terms of its commodity value and productivity), and that access to land was not in itself an inducement to sedentism, especially in the larger context of frontier politics. Wittebergen would demonstrate the tensions inherent in these connections between land, sedentism, labour, and safety.

\section{3. 'A reserve for the Aborigines'}

In 1842, Shepstone obtained permission from the Sotho chief Moshoeshoe (the area's putative paramount) to establish a mission station between the Kraai and Orange Rivers as a continuation of his collaboration with Khama. ${ }^{29}$ Shepstone and Khama erected the doubly-eponymous Kamastone mission station, which was

${ }^{24}$ Lester, 'Settlers', p. 227, 239-240.

25 lbid., p. 232-233.

26 Lester, Imperial, p. 215-216, note 127.

27 A. Lester, 'Humanitarians and White Settlers in the Nineteenth Century', in N. Etherington (ed), Missions and Empire (Oxford, Oxford University Press, 2005), p. 70-71.

${ }^{28}$ G. Theal (ed), Basutoland Records (hereafter BR), I (Cape Town, W.A. Richards and Sons, 1883), p. 126-127; Morija Museum and Archives, Lesotho (hereafter MMA), D.F. Ellenberger Papers (hereafter DFEP), letter from J.M. Orpen to J. Ayliff, 15 December 1906. Much of this archive is freely available online on the British Library's Endangered Archives platform.

${ }^{29}$ SOAS WMMS, FBN 5, A. Brigg to General Secretaries of the WMS, 14 October 1875; BR, I, p. 80. 
eventually re-named Wittebergen. ${ }^{30}$ Shepstone's ministry took in a varied congregation, including people identified as Xhosa, BaSotho, 'Tambookies', 'Bastaards', and former slaves from the Cape, ${ }^{31}$ and in a few short years their membership had swelled to 2,000 souls. ${ }^{32}$ However, Shepstone and his colleagues were constantly frustrated by unauthorised settlement and aggression from farmer incursions from the Cape to return servants to their masters, and stock raids led by settlers and Africans alike. ${ }^{33}$

These instabilities jeopardised the mission's existence, and Shepstone appealed to the Cape government with arguments premised in land title, frontier safety, and warnings of imminent genocide. ${ }^{34}$ Shepstone maintained that when he arrived, the territory surrounding Kamastone was depopulated and people were scattered by wars. ${ }^{35}$ He claimed that Moshoeshoe had given permission to Khama to establish the mission and that when Khama vacated the station (which he did shortly after its founding), the title reverted to Shepstone. ${ }^{36}$ In his later memorandum to Cape Parliament advocating for Moshoeshoe's continued rights to Wittebergen's land, the surveyor Joseph Orpen intimated that Shepstone's statements above were calculated lies. ${ }^{37}$ Shepstone's letters to the WMS nevertheless asserted his belief that he found the land vacant. ${ }^{38}$ It is possible that Shepstone was dissembling; it is also possible, as detailed below, that the logics of land use operating around Wittebergen materialised in such a way that European observers might have misinterpreted a lack of settlement as genuine vacancy.

${ }^{30}$ Confusingly, Shepstone transferred the name 'Kamastone' to the new station that he would found to the east and re-named the old station 'Wittebergen'. Hence, any reference to 'Kamastone' pertaining to 1849 and beyond refers to the later station, while 'Wittebergen' refers to the original station from 1849 and includes the reserve from 1850.

${ }^{31}$ WMMS, FBN 5, A. Brigg to General Secretaries of the WMS, 30 June 1864.

32 Western Cape Archives (hereafter CA), Government House (hereafter GH) 28/53, R. Robinson to Colonial Secretary, 20 January 1850.

${ }^{33}$ BR, IV (Roma, Institute for Southern African Studies, 2002), p. 382.

${ }^{34}$ For this last, see, CA, GH 28/53, H. Calderwood to Civil Commissioner, Victoria District, 9 May 1850; W. Porter to Office of the Attorney General, Cape Colony, 16 May 1850.

${ }^{35}$ WMMS, FBN 20, Box 315, W. Shepstone to Secretaries General, 27 December 1844.

${ }^{36}$ CA, GH 28/53, W. Shepstone to H. Calderwood, 2 July 1850; BR, IV, p. 382.

${ }^{37}$ CA, A.369, 'Memorandum drawn up by Joseph Millerd Orpen, one of the members of the Commission appointed by the Colonial Secretary's letter of the 8th February 1869, to "investigate" and "report" "with such details as may be necessary" on "all claims to land in the Wittebergen Native Reserve" including the claim of the Wesleyan Missionary Society". For a rebuttal, see CA, A.369, 'Memorandum drawn up by John Austen [...] in reply to $\mathrm{Mr}$ J.M. Orpen's memorandum'. While Orpen's fluency in BaSotho culture was patchy, as a surveyor and official representative to Moshoeshoe he was better versed in BaSotho land idioms than many contemporaries; see R. King, "'A Loyal Liking for Fair Play": Joseph Millerd Orpen and Knowledge Production in the Cape Colony', South African Historical Journal, 67, 4 (October 2015).

${ }^{38}$ E.g. WMMS, FBN 20, Box 315, W. Shepstone to Secretaries General, 27 December 1844. 
Shaw, now WMS Superintendent, proposed a solution to the land tenure question: the Wesleyans' land should be designated as a 'Reserve for the Aborigines, or persons of Native African descent, and that no farms or lands be granted within that District to persons of european [sic] race. ${ }^{\prime 39}$ Residents would be subject to colonial laws, pay taxes as the Cape government would see fit, and be subject to Cape legislation. The WMS would hold the land in trust and be allowed to build churches, schoolhouses, gardens, and cultivate fields. Harry Smith, then Governor of the Cape Colony, accepted Shaw's proposal (Figure 2). ${ }^{40}$

It is worth pausing to consider the physical and environmental landscape that Shaw and Smith agreed upon as Wittebergen's purview. Writing of the south-eastern edge of the Drakensberg range in 1840, Shepstone described a rugged and evocative place:

Imagine [...] two extensive planes - the upper and the lower. The upper plane is the table tops of innumerable mountains quite insulated [and ...] now and then intersects with a small valley [...] from whose perpendicular sides streams of water are generally pouring from fountains which burst forth from the very summit of these almost inaccessible ramparts. [...] As the traveller advances toward the Orange River, the lower plane fast becomes the larger field and one is obliged to thread the defiles between these interminable mountains like a mariner amongst the south sea islands. $^{41}$

Shepstone went on to comment that the soil was fertile, with wood being the only resource lacking. While the soil may indeed have been fertile for a time, the heavily dissected terrain that Shepstone described placed restrictions on its extent, arability, and erosional proclivity. William Beinart has discussed the putative causes of this landscape's degradation ${ }^{42}$ and I return these later. Moreover, the defiles and 'ramparts' - especially those containing rockshelters so prevalent that the dominant geological stratum is nicknamed 'Cave Sandstone' - were particularly well-suited to people who chose mobility over sedentism. I will consider these points shortly, but for now it is worth noting the tension between the WMS vision of an agriculturally vibrant community and the physical and social forces that the landscape exerted. Apart from access to land as a spiritual and commercial asset, Shepstone explained another benefit of the Reserve:

${ }^{39} \mathrm{CA}, \mathrm{GH} 28 / 53$, W. Shaw to Colonial Secretary, 14 May 1850.

${ }^{40}$ CA, GH 28/53, Memorandum of J. Montagu to Governor Sir H. Smith, 6 June 1850; Proclamation by His Excellency Lieutenant General Sir Henry George Wakelyn Smith regarding the Wittebergen Native Reserve, 31 July 1850.

${ }^{41}$ WMMS, FBN 20, Box 315, W. Shepstone to Secretaries General, 16 July 1840.

${ }^{42}$ W. Beinart, Rise of Conservation in South Africa: Settlers, Livestock, and the Envrionment 1770-1950 (Oxford, Oxford University Press, 2003). 
It is further desirable that this tract of country be placed under British authority as it forms the key of communication between the Tambookies and Moshesh's people, who not many years back carried on to a large extent a system of Robbery and murder, in which the Korannas have also joined; and it is a fact that a mission established in that country by the Wesleyan Missionary Society has been the means of preventing the continuance of this system. Thus the government by holding that tract of country, inhabited by so mixed a population, whose ties of clanship are broken would effectually prevent the recurrence of it. ${ }^{43}$

For Shaw and Shepstone, Wittebergen could curb the threat that the WMS saw in potential collaborations between Moshoeshoe and the Thembu to the south and west, a buffer logic reminiscent of Queen Adelaide Province. Shepstone further believed that if a native reserve were created, it would attract Africans desirous of colonial service and dissatisfied with traditional leadership, who would gladly submit themselves to colonial governance rather than to their own chiefs.

\section{4. 'The locusts have no king, yet they go forth all of them by}

\section{bands'44}

Wittebergen's missionaries considered land in an idiom that linked individualism, agriculture, spiritual growth, and security contingent on compliant or weakened chiefly authority, hence the emphasis on the Reserve as a buffer zone. This buffer zone could never fully function as intended, however, as it rested on mis-perceptions of other logics of landscape and political cultures operating around the Reserve. Territorialising Wittebergen's populace neither replicated nor created selfcontained, sedentary societies. In part, this is because so many Highveld and eastern Cape societies were fundamentally incorporative, capable of amalgamating newcomers through obligatory relationships inhering in cattle and (fictive or real) kin structures. ${ }^{45}$ Additionally, WMS missionaries and Cape officials perceived certain polities outside the Reserve as landless and disorganised when this was not the case. Establishing the history of the area around Wittebergen prior to the Reserve's creation was a particular preoccupation of Orpen and the French missionary D.F. Ellenberger. For the former, researching histories of settlement by African chiefs fed a larger interest in asserting African land rights within the treaties establishing Basutoland's borders. For the latter, understanding how Basutoland's southern and western regions became incorporated into Moshoeshoe's state was central to the

\footnotetext{
${ }^{43}$ CA, GH 28/53, W. Shepstone to H. Calderwood, 2 July 1850.

${ }^{44}$ A. Brigg, 'Sunny Fountains' and 'Golden Sand': Pictures of Missionary Life in the South of the 'Dark Continent' (London, T. Woolmer, 1888), p. 148.

45 P.S. Landau, Popular Politics in South Africa, 1400-1948 (New York, Cambridge University Press, 2010), p. xiii, 64.
} 
'Third Period' of his opus History of the Basuto. The Third Period was never published but in the process of compiling it, Ellenberger and Orpen carried out an extensive programme of research and correspondence. Both were flawed investigators: Orpen was often too narrowly concerned with legal minutiae and Ellenberger doubted the accuracy of African historical memory. ${ }^{46}$ But their paper trail leads to characterisations of Wittebergen as a major thoroughfare for cattle raiders and, by extension, commandos. Working in archives of the Secretariat for Native Affairs, frontier publications like the Grahamstown Journal (which they viewed with scepticism), and recruiting memoirs from colleagues and African informants, Ellenberger and Orpen chronicled accounts of raids and retaliatory skirmishes from the early 1830s. ${ }^{47}$ Later historians have further illustrated how this area of the south-eastern Drakensberg and adjoining lowlands appears to have attracted dispersed or fugitive peoples from the Cape in the early- to mid-nineteenth century, many of whom raided cattle for reasons ranging from lost herds to political defiance. $^{48}$

Ellenberger and Orpen were particularly concerned to highlight that the Phuthi chief Moorosi was recognised by both Moshoeshoe and the Cape as having authority over the Wittebergen area. They both relate accounts from Moorosi and Moshoeshoe stating that in 1835 or 1836 D'Urban acknowledged this, meaning that Wittebergen was ultimately in Moshoeshoe's borders since Moorosi was his vassal. ${ }^{49}$ What is more, Moorosi was able to assert this right within Moshoeshoe's state without being settled within his territories - at least not in what may be considered as a conventional chiefly manner of settlement.

Archival sources - including testimony from Moorosi - and the material practices they disclose aid in discerning Moorosi's logic of landscape, at least in part. Space does not permit a full recounting of his polity's practices, but of significance here is that they emphasised mobility, dispersed settlements, and social cohesion fostered through intensive cattle raiding; ${ }^{50}$ in short, behaviours that Wittebergen's authorities interpreted as threatening the Reserve's order and occupants. Ellenberger, Moorosi's eventual missionary, suggested that Moshoeshoe 'placed' Moorosi and his father Mokuoane in the 'large and alpine' country south of the Senqu River because their cattle-raiding acumen and alliances with a diverse consortium of 'Bushmen' and chiefs made them ideally suited to act as Moshoeshoe's surrogates in the

\footnotetext{
${ }^{46}$ For elaboration on these points, see E.A. Eldredge, 'Land, Politics, and Censorship: The Historiography of Nineteenth-Century Lesotho', History in Africa, 15 (1988); Landau, Popular, p. 60-61; King, '“A Loyal Liking”'.

${ }^{47}$ E.g. MMA, DFEP, J.M. Orpen to D.F. Ellenberger, 16 March 1905; J.M. Orpen to N. Moshoeshoe, 8 September 1905; D.F. Ellenberger to J.M. Orpen 10 October 1905; 15 December 1905.

${ }^{48}$ Summarised in S. Challis, 'Creolisation on the Nineteenth-Century Frontiers of Southern Africa: A Case Study of the AmaTola "Bushmen" in the Maloti-Drakensberg', Journal of Southern African Studies, 38, 2 (June 2012).

${ }^{49} B R, V($ Roma, Institute for Southern African Studies, 2002), p. 69.

${ }^{50}$ R. King, 'Living on Edge: New Perspectives on Anxiety, Refuge, and Colonialism in Southern Africa', Cambridge Archaeological Journal, in press.
} 
southern mountains. ${ }^{51}$ While Mokuoane and Moorosi were given rights to their territories in the same manner as Moshoeshoe's other 'placed' representatives, ${ }^{52}$ they did not follow the sedentary 'Great Place' trend of chiefly settlement throughout the Highveld and eastern Cape, with subordinate villages and homesteads arrayed around a relatively fixed homestead. They established a series of settlements, generally atop or at the base of steep-sided table-like kopjes (Sesotho, liqhobosheane), which they would occupy for a time before moving on to another. They returned to each of these repeatedly throughout the nineteenth century as it suited their needs, including bracing for attacks from Free State patrols, falling back from a cattle raid, or for more protracted periods of calm. ${ }^{53}$ In their absence from these preferred locales, Mokuoane and Moorosi left others there to secure them, while other BaPhuthi occupied land from around Maphutšeng in the north to Lundean's Nek and present-day Lady Grey in the south. ${ }^{54}$ These settlements included Lefika la bo Khiba, which fell squarely within the boundaries proclaimed for Wittebergen (Figure 3).

Under Moshoeshoe's chieftainship, this sort of mobility still fit within ideas of effective occupation. ${ }^{55}$ Within Moshoeshoe's state, the general principle governing land disposition was that a leader was executor of land to which his followers had multiple rights. Land for subsistence and habitation was granted not to individuals but to men on behalf of their family, with a portion of the land's increase going to chiefs. Pastureland was commonage for individual villages or wards but owing to the demands of transhumance, chiefly authority over grazing areas (including village pastures and distant cattle posts) was a mosaic of rights and negotiated access. Thus, boundaries were malleable, contouring to features as varied and overlapping as veld types, natural landforms, and politics. Settlement was a part of the regional political vocabulary, as where one lived, farmed, and grazed was as much to do with political affiliation as with kinship (to the extent that these could be separated). ${ }^{56} \mathrm{~A}$ degree of

${ }^{51}$ MMA, DFEP, D.F. Ellenberger, 'History of the Basuto, ancient and modern: Third period', unpublished manuscript, ch. 29.

52 E.A. Eldredge, A South African Kingdom: The Pursuit of Security in Nineteenth-Century Lesotho (Cambridge, Cambridge University Press, 1993), p. 36-37.

${ }^{53}$ E.g. CA, Native Affairs (hereafter NA) 276, J. Austen to C. Griffith, 7 May 1879; MMA, Marion Walsham How Papers, Notes taken end of November 1930 from Mapote son of Moorosi at Qacha's Nek.

${ }^{54}$ MMA, DFEP, J.M. Orpen, 'Statement by Morosi, alias Mogorosi, in 1859 of the genealogy of the Baputi chiefs. Subject to the Basuto of Moshesh',1876; King and Challis, 'The Interior World'.

55 The arrival of the British Administration in Basutoland (1871) and the later adoption of the Laws of Lerotholi (1906) codified real property laws in Basutoland and consequently extracting cultural understandings of land tenure from official reports after these events becomes difficult. The discussion here draws on E. Casalis, The Basutos (Morija, Morija Museum and Archives, 1861); D.F. Ellenberger, History of the Basuto, Ancient and Modern (Morija, Morija Museum and Archives 1912); S. Burman, Chiefdom Politics and Alien Law: Basutoland under Cape Rule, 1871-1874 (London, Macmillan, 1981); Eldredge, South African.

${ }^{56}$ Eldredge, South African, p. 31; Landau, Popular, ch. 1. 
'un-settlement' was therefore common, with people moving as chiefly houses split or were 'placed' in new locations.

Recalling Moshoeshoe's statement earlier, land - not necessarily sedentism or a Great Place - distinguished a chief from a Moroa. Moorosi's expression of chieftaincy appeared to satisfy both Moshoeshoe's desires and the polity's needs for subsistence and livestock. In the rugged southern Maloti-Drakensberg Mountains, where topography restricts extensively agglomerated settlement, mobility was arguably an asset for chiefs fulfilling obligations to a dispersed community, as well as executing cattle raids to the west, east, and south beyond the Drakensberg Escarpment. BaPhuthi leaders were able to assert and retain authority over their territories because they were itinerant within these, rather than their mobility negating effective occupation. ${ }^{57}$ That WMS and Cape representatives may have interpreted Moorosi's absence from his settlements within Wittebergen's proposed boundaries as abrogation of these settlements is perhaps understandable, given the different logics of mobility at work within European and BaPhuthi societies. Inherent in Moorosi's and Moshoeshoe's logics of landscape were conflicts with those of Wittebergen's authorities and missionaries. Where the WMS saw the Reserve in terms of cultivation and buffer zones, Moorosi's BaPhuthi treated it as a node in a mobile network of settlements and raiding locales. This network - and cattle raiding more broadly - drew in the dislocated and politically dissatisfied constituency that Wittebergen hoped to attract. The Reserve thus became a contest over mobility and treatments of land and space - a contest that fed into the production of a Christianised rural labour force.

\section{5. 'Headless hordes' and 'banditti of robbers'}

Wittebergen was a bilateral administration between the Cape and the WMS: missionaries had jurisdiction over the mission and school, while the Superintendent of the Reserve (appointed by the Cape) presided over legal matters, including settlement rights and tax collection. Gardens, fields, and the church were the institutions through which the cultural transformation of the Reserve's population would take place. ${ }^{58}$ Residents were required to register with the Superintendent and those who did not - dubbed 'squatters' - were subject to arrest. ${ }^{59}$

'Squatters' here is reminiscent of the 'vagrants' that Cape settlers and authorities saw as unregulated and under-utilised bodies. Elizabeth Elbourne has noted that in the unsuccessful Cape vagrancy legislation of 1834, 'vagrancy' was effectively equivalent to 'behaving as a hunter-gatherer': itinerant, foraging for wild food instead of seeking lawful employment. ${ }^{60}$ When conversations about vagrancy legislation came again to the fore from the mid-1840s, they were still rooted in

\footnotetext{
${ }^{57}$ R. King and S. Challis, 'The Interior World of the Nineteenth-Century Maloti-Drakensberg Mountains', Journal of African History, in press.

${ }^{58}$ Brigg, 'Sunny', p. 144.

${ }^{59} \mathrm{CA}, \mathrm{GH}$ 14/27, J. Austen to Burnet, 22 October 1859.

${ }^{60}$ E. Elbourne, Blood Ground: Colonialism, Missions, and the Contest for Christianity in the Cape Colony and Britain, 1799-1853 (London, McGill-Queen's University Press, 2002), p. 237, 257-258, 275.
} 
concern over Africans' unwillingness to become farm labourers. George Southey's definition of vagrants as 'living in idleness without any means of subsistence, and that they have refused to work when offered unemployment upon fair and reasonable terms' suggests a continued association of vagrancy with a lack of commitment to cultivation or sustainable subsistence. ${ }^{61}$ Unlike 'vagrants' at the Cape, 'squatters' in Wittebergen were not expected to work on settlers' farms. They were guilty of failing to commit to settled farming - to transform into agriculturists who could pay their hut taxes and thus offer a source of revenue for the Cape. Moreover, squatters were a source of worry both because their presence in the Reserve was unregistered and because of their potential involvement in cattle raiding.

Indeed, stopping cattle raiding in and around the Reserve and perpetuated by or upon residents was a significant concern. This was particularly the case given the prevalence of raiding in the surrounding area and the threat that this posed to the Reserve's security. Victims of stock theft (African and European) would often pursue suspects into the Reserve, making the Reserve a lightning rod for armed conflict. ${ }^{62}$ The missionaries and the Reserve's administration attempted to create idealised versions of African villages, tribalising residents according to perceived ethnicity and locating them within settlements that merged supposed traditional customs with civilised ones. Authorities identified different ethnic groups (on what basis is unclear) and allocated them to discrete areas of the Reserve with their own settlement styles: 'Fingoes' lived in clusters of kraals praised for their cleanliness, whitewash, and thatch under their own headmen; BaSotho lived in another part of the station under an elected chief and in wattle-and-daub or brick houses deemed less clean than those of 'Fingoes'; and 'Bruin menschen' (mixed race 'Bastaards' or former slaves) lived in small villages comprising brick houses and an ambiguous semi-democratic form of government. ${ }^{63}$ Chiefs and headmen were given the power to govern their respective kraals and villages and settle minor disputes, while anything more serious was referred to the Superintendent. Each homestead head was given one plot of arable land per wife, upon which she grew maize and sorghum as the main crops, although wheat, oats, beans, and potatoes were also grown in some fields. ${ }^{64}$ Given the Reserve's focus on sedentism and cultivation, in addition to the gardens pertaining to each homestead five arable lots were designated within the Reserve for use by residents (Figure 4). ${ }^{65}$ Each village was further allotted summer and winter pasturage for its exclusive use.

${ }^{61}$ C. Crais, White Supremacy and Black Resistance in Pre-Industrial South Africa: The Making of the Colonial Order in the Eastern Cape, 1770-1865 (Cambridge, Cambridge University Press, 1992), p. 142.

${ }^{62}$ E.G. BR, IV, p. 382; CA, GH 14/27, J. Austen to Burnet, 4 February 1860 and 1 April 1860.

${ }^{63}$ Brigg, 'Sunny', p. 106-107.

64 WMMS, FBN 5, A. Brigg to Secretaries General of the WMS, 13 August 1868; Bradford, 'Peasants', p. 92-93.

${ }^{65}$ Surveyor General (henceforth SG), Herschel Documents 646-649/1860 and TR2092/1861, available online at http://csg.dla.gov.za, accessed 31 August 2015. 
Inasmuch as this scheme broadly echoed Sotho and Tswana systems of land disposition, the crucial difference was that no part of the agricultural or stock increase was returned to chiefs or headmen, nor (theoretically) would they be paid to Wittebergen officials. As the Reserve aimed to create a rural labour force by enabling residents to acquire and retain property and produce, the chiefly prerogative to claim some or all of the gains of village residents, whether for personal use or as public goods, was removed. Elaborating upon Bundy's statement that Wittebergen's refugee population lacked big chiefs and therefore was open to surplus production, ${ }^{66}$ traditional leadership was not so much absent as devolved to a more local level and carefully gutted in its control over land tenure and agriculture. ${ }^{67}$ The Reserve's policies towards residents were shaped definitively during the tenure of its second Superintendent, John Austen. Austen administered the Reserve through a combination of African and Western law, as he interpreted these. ${ }^{68}$ For a time he was considered a suitable authority figure: he spoke 'English, Dutch \& Kafir with equal fluency $\&$ showed considerable tact in the management of the numerous clans $\&$ tribes represented in the district.. ${ }^{69}$ This number grew in large part through the efforts of the mission station: after Shepstone's departure for the relocated Kamastone mission station, successive missionaries reported the settlement of a large number of diverse peoples in the Reserve. ${ }^{70}$

The mission station (Figure 5) was the social centre of gravity in this arrangement but despite efforts to consolidate the Reserve's population, a large number of people lived at a remove from it. Mission sub-stations were established among 'Fingo' and 'Bastaard' communities already residing in the area but unwilling or unable to move more fully within the mission station's ambit. ${ }^{71}$ These sub-stations seem to have persisted during the life of the Reserve as fairly informal and almost certainly overseen by African ministers; ${ }^{72}$ unfortunately, the paucity of written records either produced by these ministers or retained by the WS means that they (along with most of their parishioners) number among Wittebergen's historically silenced communities. Both European and African missionaries' work included itinerant preaching at the edges of the Reserve and throughout the surrounding

${ }^{66}$ Bundy, 'Peasants in Herschel: A Case Study of a South African Frontier District', in S. Marks and A. Atmore (eds), Economy and Society in Pre-Industrial South Africa (London, Longman, 1980), p. 210-211.

${ }^{67}$ Cf. Beinart, 'Amafelandawonye', p. 230.

${ }^{68}$ For accounts of Austen's competence and eventual removal, see CA, CA, Colonial Office (hereafter CO) 4164, J.M. Orpen, 'Regarding John Austen's Unfitness To Be Superintendent of Natives near Aliwal North'; BR, V, p. 237, 266.

${ }^{69}$ MMA, DFEP, D. Brigg, 'Notes on the early history of Herschel Native Reserve, Aliwal North, Cape Colony', ND 1906, emphasis original.

70 Between 1848 and the late 1870s these included Johannes Bertram, Gottlob Schreiner, John Daniel, Arthur Brigg, and Richard Giddy.

${ }^{71}$ CA, GH 28/53, J.P. Bertram to Assistant Surveyor General, 26 March 1850.

72 WMMS, FBN 14, A. Brigg to Secretaries General of the WMS, 4 June 1861; FBN 5, A. Brigg to Secretaries General of the WMS, 13 August 1868. 
region. Arthur Brigg described how his wanderings took him to the kraals of 'Batlokuoa', 'Mantatees', and 'Amahlubi', representing peoples who had been dispersed following earlier violent conflicts elsewhere in the subcontinent. ${ }^{73}$ Despite the missionaries' emphasis on settlement and cultivation close to the mission station, creating sub-stations and itinerant preaching circuits was an acknowledgment of the practicalities of dealing with populations that were unavoidably mobile or resistant to cultivating the Reserve's main arable plots. Seen another way, missionaries' logic of landscape had to capitulate to what their parishioners were willing to accept. Additionally, while many people living at these peripheries requested the presence of a missionary among them and even occasionally attended services at the main station, it was at this remove that Wittebergen's project was the most fragile. These communities were under less supervision and therefore more vulnerable to both the depredations and temptations of itinerant and raiding lifestyles than those residing closer to the station. To the extent that we can conceive of Wittebergen as adhering (at least in part) to the mission-as-beacon model, we can consider the Reserve's social and Christian landscape as tracing axes of public adherence to spiritual and agricultural projects; the farther from the station one was, the less public one's Christian persona could be.

For Wittebergen's missionaries, the establishment of permanent, idealised settlements, with rights to arable land residing with their occupants rather than chiefs, constituted a transformation of the Wittebergen landscape, its inhabitants, and their political culture. Following Lester, this was a paternalism that combined closely-monitored bourgeois morality with commerce, and which held transformative potential for the entire social and physical landscape. ${ }^{74}$ In accounts rife with agricultural imagery, such as Bertram's statement above, missionaries described how the country was flourishing through the preaching of the gospel. Bertram stated his belief that owing to the influence of Christianity and its attendant institutions, the station's residents who hitherto 'could never live without continual war' were now able to live in peace. ${ }^{75}$ The mission station was not only capable of reforming those willing to live under 'the banner of the cross', but also of sowing a seed of peace that could calm an entire region troubled by marauders. The duty of the many native assistants and African preachers recruited by Wittebergen's missionaries was to help this seed spread beyond the focal point of the station. While Bertram's and others' early accounts described Wittebergen's spiritual and agricultural bounty, within scarcely more than twenty years these were turned on their heads. From 1850 to the mid-1860s, largely as a result of violent conflicts from the Cape and between Boers and BaSotho, the Reserve's population rose from around 2,000 to around 22,600, straining the already limited carrying capacity of the

\footnotetext{
73 Brigg, 'Sunny', p. 132, 134.

${ }^{74}$ Lester, Imperial, p. 60.

${ }^{75}$ WMMS, FBN 20, Box 315, J.P. Bertram to Secretaries General of the WMS, 9 November 1849.
} 
Reserve's land and the quantity of land available. ${ }^{76}$ Drought was common and devastating. Brigg wrote at least twice to WMS officials, asking that the station relocate east to the more temperate site of Bensonvale, saying: 'The people here [...] live on "rocks", thence cannot grow rich nor contribute to the cause of God' (Figure 6). ${ }^{77}$ In its isolation, the Reserve struggled to acquire medical provisions and the combination of overcrowding and environment led to a rise in illness. ${ }^{78}$ This trajectory fits with Bundy's thesis that the rise of the rural peasantry was swiftly followed by a fall due to a lack of arable land, overpopulation, indebtedness, and environmental stress. However, Beinart has shown that that perceptions of environmental distress were often rooted in European ideas about conservation and supposed African 'mis-management', rather than representing enduring environmental conditions. ${ }^{79}$ The point I want to draw out here is that inasmuch as land was a major physical and symbolic component of mission, at Wittebergen the land itself would not always cooperate. That landscape could operate in different ways and with different meanings was a challenge for Wittebergen's missionaries in terms of practice and Christian teachings, and is echoed in the Reserve's 'buffer logic'.

At the outer periphery of the Reserve were Moorosi, his BaPhuthi, and other cattle raiders. According to Ellenberger, in the years following the Reserve's founding, 'Moorosi still held sway [over the Wittebergen area] and exercised his rule in the territory unaware of any political or geographic change. ${ }^{80}$ Officials within the Reserve were initially compelled to recognise this authority: when James Ayliff, the Reserve's first Superintendent, was required to register residents, he admitted that he could only do so once Moorosi was consulted. Additionally, Moshoeshoe seems to have assured Moorosi that those lands south of the Senqu and west of the Tele were still under the latter's jurisdiction. ${ }^{81}$

Nevertheless, by 1859 Moorosi had been expelled from the Reserve (the reason is unclear) and in doing so Moorosi had thereby forfeited his and Moshoeshoe's rights to occupy the eastern end of the Reserve, according to the Cape's interpretation of land tenure. ${ }^{82}$ However, although Wittebergen's amputation of Moorosi's territory limited his access to and movement within the Reserve, Moorosi's mobile form of chieftainship allowed him to re-shape his polity and his territories. Moorosi and his BaPhuthi withdrew to their settlement across the Tele River at Bolepeletsa and re-

\footnotetext{
${ }^{76}$ CA, GH 28/53, R. Robinson to Colonial Secretary, 31 March 1850; BR, III (Cape Town, W.A. Richards and Sons, 1883), p. 238; Brigg, 'Sunny', p. 106; cf. Bradford, 'Peasants', p. 93.

77 WMMS, FBN 14, A. Brigg to Secretaries General of the WMS, 27 July 1863; FBN 20, A. Brigg to W. Boyce, 7 September 1870, emphasis original.

78 WMMS, FBN 5, A. Brigg to Secretaries General of the WMS, 20 July 1864.

${ }^{79}$ Beinart, The Rise, p. 336-339.

${ }^{80}$ MMA, DFEP, D.F. Ellenberger, 'History of the Basuto, ancient and modern: Third period', unpublished manuscript, ch. 29.

${ }^{81}$ MMA, DFEP, J.M. Orpen, 'Extracts from Official Papers', 5 July 1911.

${ }^{82}$ BR, III, p. 106-107.
} 
oriented their cattle raiding to take in the Reserve and areas farther eastward through the Maloti-Drakensberg Mountains and into Natal. ${ }^{83}$

To Wittebergen's authorities, it appeared that Moorosi had 'let loose his thieves upon the border, and [...] taken to himself the position at the head of a Banditti of robbers. ${ }^{84}$ Skirmishes and gunfights took place near Wittebergen's borders, with residents of both the Reserve and neighbouring towns attempting to impose order, adding to the atmosphere of unruliness on the fringes of the Cape and mission authority. ${ }^{85}$

Within the Reserve, roads, gardens, and kraals became sites of contest as Moorosi's BaPhuthi struggled to assert their mobility and access to resources such as crops and livestock. Austen barred Moorosi from gardens that he had planted prior to his expulsion. This was especially significant as BaPhuthi appear to have relied more heavily on horticulture than field agriculture, meaning that this exclusion impacted BaPhuthi subsistence and economy. Moorosi used trails through the Reserve to provision his polity, primarily with traded goods and ammunition. Austen responded by blocking at least one of these. ${ }^{86}$ Officials suspected that Moorosi had followers or at least occasional raiding partners from the Reserve, to which was added concerns that the raids occurring around the Reserve were stimulating lawless activity within it. ${ }^{87}$ Austen reported that BaPhuthi were slaughtering animals belonging to the mission station and confiscating stock and crops from people within Wittebergen. In one such incident, Austen described how one of Moorosi's sons confiscated the livestock of a resident because the resident must have been spying for Austen, given Austen's detailed knowledge of Moorosi's theft. ${ }^{88}$

In these and other raids, the landscape became an advantage for mobile raiders mounted on horseback, like Moorosi and his BaPhuthi. Settlements atop liqhobosheane were useful not only as easily-defensible refugia for people and goods, but also as vantage points from which to observe the movements of, for instance, commandos. ${ }^{89}$ For those not tied to field agriculture, the Maloti-

Drakensberg Mountains and their adjoining lowlands offered opportunities to range across diverse political and environmental spaces while remaining beyond the reach of people and apparatuses (i.e. military forces) that struggled with the rugged terrain. Ultimately, Moorosi and his BaPhuthi were spatially constrained by factors such as Basutoland's 1871 annexation to the Cape and the establishment of surveillance infrastructure like magistracies and police stations.

\footnotetext{
${ }^{83}$ King and Challis, 'The Interior World'.

${ }^{84}$ BR, IV, p. 449. Cf. R. King, 'Cattle, Raiding, and Disorder in Southern African History', Africa, in press.

${ }^{85}$ CA, CO 4164, J.M. Orpen to J. Austen, 9 October 1865; MMA, DFEP, J.M. Orpen to J. Ayliff, ND 1906; J.M. Orpen to D.F. Ellenberger, ND 1907.

${ }^{86} B R, I V$, p. 271.

${ }^{87}$ CA, GH 14/27, J. Austen to Burnet, 2 February 1859; J. Austen to Burnet, 4 February 1860.

${ }^{88} B R$, IV, p. 522.

${ }^{89}$ King, 'Living on Edge'.
} 


\section{Denouement: Of land and labour}

In 1869 and 1870, residents of the Wittebergen mission and adherents of Rev'd. Brigg successfully petitioned Cape Parliament to declare illegal activities that resulted in the confiscation of their property by headmen, Reserve constables, and the local Frontier Armed Mounted Police. Bundy identified this as a significant moment in the birth of Herschel District's rural peasantry but it was also a milestone for the WMS: Wittebergen's Christian community had collectively spoken in favour of 'progressive' land tenure and property ownership..$^{90}$ Over the next decade, Wittebergen saw either the continued escalation or halting expansion (whether one defers to Bundy or Bradford) of stock and grain farming, and the mission station continued to attract converts and developed a robust Christian community that persisted into the twentieth century. Moorosi's BaPhuthi re-oriented their movements according to the constricting borderlands between the Cape and what would become Basutoland. They launched a failed rebellion against Basutoland authorities in 1879, which led to the dispersal of the polity throughout the southern Drakensberg.

Taking land as idiom and object, this paper has drawn out three aspects of Wittebergen's late-nineteenth-century existence: the Reserve was a contest over controlling African mobility; 'traditional' land use and occupation were multi-faceted and open to wide mis-interpretations; and while the Reserve aimed to create a Christian rural labour force, this labour force and its presence on the landscape was intended to serve as a cordon against specific geo-political threats. We can thus conceive of the rural protests and perceived landscape degradation that Beinart described for early twentieth-century Herschel as yet another shift in logics of landscape. Nineteenth-century Reserve programmes focused on encouraging sedentism, but by the late 1920s Transkeian authorities were concerned that this sedentism was of the wrong sort: animals were overstocked, arable plots needed fencing to control livestock mobility, and erosion had to be curbed. 'Land' gave way to 'soil' as the key to African upliftment and development. ${ }^{91}$

Wittebergen offers much in the way of further research on themes only touched upon here, but above all this essay has aimed to signpost an approach to action, land, and material culture as statements accessible through multiple sources. This sort of archaeological perspective foregrounds the linked agency of things and people visible both in text and on the landscape - to consider, in other words, a broader range of actors creating the material world of mission in southern Africa.

\footnotetext{
${ }^{90}$ Bundy, Rise and Fall, p. 147-148.

${ }^{91}$ Beinart, Rise of Conservation, p. 341, 345.
} 